\title{
WHY NEW ZEALAND EMPLOYERS SHOULD BE SUBJECT TO MANDATORY PAY TRANSPARENCY
}

\author{
Amanda Reilly*
}

\begin{abstract}
This article argues that New Zealand employers should be subject to mandatory pay transparency as a means of addressing the gender pay gap. This would help employers to comply with their legal obligations not to discriminate against women, and it would aid in the enforcement of the law. It would also ameliorate inequality of bargaining power and encourage employers to appoint and promote based on legitimate criteria. The article also provides some recommendations to guide the design of an optimal pay transparency regime; it should be universal and accessible, with penalties and incentives around both reporting and improving performance.
\end{abstract}

\footnotetext{
* Senior Lecturer in Commercial Law, Wellington School of Business and Government, Victoria University of Wellington.
} 


\section{INTRODUCTION}

The gender pay gap in New Zealand stands at $9.3 \%$, where it has stood for the past decade. ${ }^{1}$ This tells us that there is inequality between men and women, ${ }^{2}$ and that matters are not improving.

The gender pay gap does not tell us what is happening in individual workplaces, but there is research that shows that discrimination is a contributor to inequality between men and women. ${ }^{3}$ This may be systemic, individual, or restricted to certain parts of an organisation. This is disappointing, considering that discrimination is prohibited by New Zealand law in the Employment Relations Act 2000, ${ }^{4}$ the Human Rights Act 1993, ${ }^{5}$ and the Equal Pay Act $1972 .{ }^{6}$ Not only does domestic law prohibit discrimination against women, New Zealand is bound by various international instruments that make it imperative for inequality to be addressed. For example, the Convention on the Elimination of All Forms of Discrimination against Women art 11 states:

Parties shall take all appropriate measures to eliminate discrimination against women in the field of employment in order to ensure, on a basis of equality of men and women, the same rights, in particular: ... (d) The right to equal remuneration, including benefits, and to equal treatment in respect of work of equal value, as well as equality of treatment in the evaluation of the quality of work. ${ }^{7}$

Pay transparency is increasingly recognised as essential for the elimination of pay gaps. The International Labour Organisation Committee of Experts has emphasised this, and the Council of Europe's European Committee of Economic and Social Rights has ruled that, as part of their positive obligation to address the gender pay gap, States must encourage/require transparency, including by publication. ${ }^{8}$ At a national level, a number of countries have introduced legislative

\footnotetext{
1 'Gender Pay Gap', Ministry for Women (Web Page, 2020) < https://women.govt.nz/work-skills/income/genderpay-gap $>$. This is measured by median hourly earnings as of August 2019.

${ }_{2}^{2}$ The focus here is on inequality between men and women but it is acknowledged that transgender and non-gender conforming individuals frequently encounter discrimination and disadvantage in the workplace. This is an important issue but not one it is possible to do justice to in this article, so it will not be further addressed here.

${ }^{3}$ See, generally, Gail Pacheco, Chao Li and Bill Cochrane, Empirical Evidence of the Gender Pay Gap in New Zealand (Report commissioned by Ministry for Women, New Zealand Government, March 2017) $<$ http://women.govt.nz/work-skills/income/gender-pay-gap/research-evidence-gap-new-zealand>.

${ }^{4}$ Employment Relations Act 2000 (NZ) s 104.

${ }^{5}$ Human Rights Act 1993 (NZ) s 22.

${ }^{6}$ Equal Pay Act 1972 (NZ) s 2 A.

7 Convention on the Elimination of All Forms of Discrimination against Women, opened for signature 18 December 1979 (entered into force 3 September 1971). Equal Remuneration Convention, opened for signature 29 June 1951, ILO Convention 100 (entered into force 23 May 1953) also requires Member States to promote and ensure equal remuneration for work of equal value. This is reinforced by Discrimination (Employment and Occupation) Convention, opened for signature 23 June 1958, ILO Convention 111 (entered into force 25 June 1958); see also International Covenant on Economic Social and Cultural Rights, opened for signature 16 December 1966, 993 UNTS 3 (entered into force 3 January 1976) art 7(a)(i), wherein the States Parties 'recognize the right of everyone to the enjoyment of just and favourable conditions of work'.

8 Jill Rubery and Aristea Koukiadaki, Gender, Equality and Diversity Branch, International Labour Office, Closing the Gender Pay Gap: A Review of the Issues, Policy Mechanisms and International Evidence (Report, 2016) 33 .
} 
requirements that require employers to report on various gender equality indicators. ${ }^{9}$ Moreover, there is increasing evidence that pay transparency is effective at reducing pay gaps. ${ }^{10}$

It is recognised within New Zealand that there is a need for gender pay transparency. The Green Party introduced a Bill to Parliament providing for this in 2017 (which was withdrawn at its first reading). ${ }^{11}$ The Human Rights Commission has been a strong and consistent advocate for pay transparency, calling repeatedly for the government to enact 'legislation enforcing a requirement that companies with more than 100 workers publicly report annually on their gender pay, bonus gaps and other EEO metrics to track progress' ${ }^{12}$ Most recently, the Human Rights Commission has launched an online petition demanding an independent pay transparency agency to close the gender pay gap. ${ }^{13}$ The government itself has recognised the need for pay transparency. The Gender Pay Principles, which the government recently negotiated with the Public Service Association (the largest public sector union), include Principle 2, which explicitly states: 'Transparency and accessibility is essential to the sustainable elimination of gender pay gaps.' 14

Yet, despite this apparent consensus, the New Zealand government does not appear to be taking any active steps toward introducing pay transparency requirements. The purpose of this article is to contribute to the argument that New Zealand should introduce mandatory universal pay transparency.

The remainder of this article begins with a review of existing law in New Zealand. This is followed by the argument that the law should change - pay transparency aids in the enforcement of the law as well as helping employers to comply with the law, and improves employee bargaining power while reducing the need for bargaining. Privacy and cost concerns are also addressed. Some principles to guide the design of pay transparency are then discussed. This all leads to the conclusion that it is time for New Zealand to be made subject to gender pay transparency.

\footnotetext{
9 This includes the United Kingdom, Australia, Iceland and some Canadian states.

${ }^{10}$ See, for example, Morten Bennedsen et al, 'Do Firms Respond to Gender Pay Gap Transparency?' (Working Paper No 25435, National Bureau for Economic Research, January 2019); Cynthia Estlund, 'Extending the Case for Workplace Transparency to Information about Pay' (2014) 4 UC Irvine Law Review 781, 786; Rubery and Koukiadaki (n 8) 32.

11 Equal Pay Amendment Bill 2017 (NZ) <https://www.parliament.nz/en/pb/bills-and-laws/bills-proposedlaws/document/BILL_72692/equal-pay-amendment-bill>.

12 See, for example, Human Rights Commission, Tracking Equality at Work 2018: Summary and Recommendations (Report, 27 June 2018) 12; Margaret Wilson, 'Pay Equality Bill' in New Zealand Human Rights Commission, Tracking Equality at Work (Report, June 2011) 36-38.

13 'End Pay Secrecy: Demand an Independent Pay Transparency Agency to Close the Gender Pay Gap', Demand Pay Transparency, NZ Human Rights Commission (Online Petition, 2019) <https://action.hrc.co.nz/end-paysecrecy>.

14 'Gender Pay Principles', Ministry for Women (Web Page, 2020) Principle $2<$ http://women.govt.nz/workskills/income/gender-pay-gap/gender-pay-principles>.
} 


\section{EXISTING LAW}

There is no legislative requirement for pay transparency in New Zealand, even though, as mentioned above, the government itself has identified pay transparency as playing an important role in closing the gender pay gap. ${ }^{15}$

The government's Gender Pay Principles establish that some limited gender pay gap information must be audited and published annually. Core public service organisations must report to the State Sector Commission on their gender pay gaps and include information on the action they are taking to address them in their four-year strategic plans. ${ }^{16}$ The State Sector Commission's annual Human Resources Capability survey publishes this information. ${ }^{17}$

While it could be seen as a positive step that some transparency is now required, the very limited scope of it is disappointing. The gender pay gap information is not easy to find on the State Sector Commission's website, and it is not individualised. Agencies with small numbers of employees do not have their gender pay gaps reported for reasons of confidentiality. The logic as to why reporting is confined to the core public sector is unclear when a much wider range of organisations are recipients of public funding (for example, crown entities and universities).

As far as the private sector goes, there are also no legislative requirements for transparency. NZX listing rules 3.8.1(c) and 3.8.1(d) require certain gender information - that is, a quantitative breakdown of the gender composition of directors and officers - to be included in an issuer's annual report. ${ }^{18}$ Some leading private sector organisations have undertaken a voluntary reporting obligation, for example, the members of the Champions for Change initiative report on representation. ${ }^{19}$ However, their goal is diversity rather than equality, and they do not report on actual wage gaps.

\section{ARGUMENTS FOR PAY TRANSPARENCY}

There are already laws prohibiting discrimination. If inequality is to be addressed, these laws must be enforced and complied with. Pay transparency can contribute to both.

\footnotetext{
15 Ibid.

${ }^{16}$ Public service departments are defined in the State Sector Act 1988 (NZ) s 27 as comprising the departments specified in sch 1 of the Act. As at 30 June 2018 there were 32 public service departments.

17 'Drill Down Data Cubes 2018', State Services Commission (Web Page, 13 December 2018) $<$ https://ssc.govt.nz/resources/public-service-workforce-datadrill-down-data-cubes>. Note that '[a]gencies with small numbers of employees have not had their gender pay gaps reported due to the impact this may have on confidentiality or data quality'.

18 'NZX Listing Rules', NZX (Web Page, 1 January 2019) <https://www.nzx.com/regulation/nzx-rulesguidance/main-board-debt-market-rules $>$.

${ }^{19}$ Champions for Change, Diversity Report 2019: Results and Analysis on the Measurement of Gender and Ethnicity at Leadership Tiers in New Zealand Businesses (Report, October 2019) $<$ https://www.championsforchange.nz/assets/Uploads/Diversity-Report-2019.pdf>.
} 


\section{A Transparency Aids Law Enforcement}

Transparency would aid in the enforcement of the law, ${ }^{20}$ and it is important that pay information should be available before legal action is undertaken. It is impossible otherwise to know whether or not there are grounds for legal action. Not requiring this gives employers the upper hand and creates opportunities for bad faith delay and obfuscation in the name of privacy.

At present, without pay transparency, an individual woman can suspect that she is subject to discrimination relative to a male colleague, but she cannot know. Pay transparency provides individuals and groups with the information needed to inform complaints and trigger claims. ${ }^{21}$

The Equal Pay Amendment Bill, which is currently at Second Reading stage in New Zealand's Parliament, will, if enacted, create a right to request information in pay equity claims, but only once the claim has been made. ${ }^{22}$ This provision will only apply in pay equity claims that arise in a highly specific situation where a group of women, such as care workers, claim they are in a sector that has historically been female-dominated and undervalued. It would be much more useful for women in these sectors to have this information prior to raising a claim.

Pay transparency can also empower third parties like unions or state agencies, such as the Human Rights Commission, to take enforcement action where discrimination is apparent. ${ }^{23}$ Potentially publicly available information on particularly egregious pay gaps may also generate media attention and public pressure for improvement.

\section{B Transparency and Employer Compliance}

Although it is important that litigation remains an option of last resort for individuals and groups, ideally employers acting in good faith would monitor their own performance and make the necessary changes. Regulators and unions have limited resources, and the cost for individual women who resort to litigation is high and success far from certain.

Moreover, enforcement through litigation is a crude mechanism for addressing gender inequality, which has multiple causes. Some inequality may be due to identifiable acts of employer discrimination, but women's socialisation and broader social forces may also play a part. Litigation as a tool implies that someone identifiable is at fault, but sometimes, as identified by Ramachandran, no one actor is necessarily to blame. ${ }^{24}$

No good employer intends to contravene the law, but it is easy to assume that since there is no intent to discriminate, discrimination must not be occurring. An employer as a whole may be committed to gender equality, but middle managers or supervisors may not be or may not

\footnotetext{
${ }^{20}$ Estlund (n 10) 785.

${ }^{21}$ See, generally, ibid.

${ }^{22}$ Equal Pay Amendment Bill 2019 (NZ) cl 13K < https://www.parliament.nz/en/pb/bills-and-laws/bills-proposedlaws/document/BILL_80319/equal-pay-amendment-bill>.

${ }^{23}$ See, generally, Rubery and Koukiadaki (n 8) 32.

${ }^{24}$ Gowri Ramachandran, 'Pay Transparency' (2012) (116)4 Pennsylvania State Law Review 1044.
} 
realise that they are discriminating against women. A transparency regime requiring employers to 'know and show' what is happening in their organisation leaves discrimination with no place to hide.

A process of careful scrutiny of pay disparity can help employers prevent discrimination from arising in the first place. Knowing that decisions will be subject to scrutiny and that disparities will have to be justified on non-discriminatory grounds will lead to fairer and better processes. ${ }^{25}$ An employer who becomes aware of inequality is best placed to identify its causes and address it. It may be a rogue individual who must be dealt with, or it could be that some change, such as more family-friendly hours, is both desirable and possible.

Furthermore, as identified by Fung, Graham and Weil, ${ }^{26}$ transparency can change internal priorities. It can empower managers who want to see change to advocate for change, and it keeps gender equality on the agenda as well as providing employers with a benchmark against which to measure their progress.

\section{Improvement of Women's Bargaining Power and Reduction of the Need to Bargain}

One of the stated objectives of New Zealand's main piece of employment legislation, the Employment Relations Act 2000 (NZ), is to acknowledge and address the inherent inequality of bargaining power in employment relationships. ${ }^{27}$ Despite this, New Zealand's law does not recognise or address a fundamental inequality with regards to pay information. Although there are some workplaces that have collective contracts in place where pay scales may be apparent, generally employers have pay information and employees do not. Effectively, women employees (who have less power) are expected to negotiate entry salaries and pay increases and to enforce discrimination law while lacking vital information. Indeed, not only do women have less bargaining power than employers, they may have less bargaining power than men in that they could have less access to information through segregated social networks. ${ }^{28}$

As well as the disadvantage produced by the information deficit, there is some evidence that women have weaker negotiation skills, particularly when they are negotiating for their own interests. ${ }^{29}$ Often women have been socialised not to value themselves as highly as men and discouraged from individualistic self-promotion, which is perceived as inappropriate and unfeminine. In fact, women who initiate negotiation are frequently penalised for this. ${ }^{30}$ Social

\footnotetext{
${ }^{25}$ See, generally, Estlund (n 10) 786.

26 Archon Fung, Mary Graham and David Weil, Full Disclosure: The Perils and Promise of Transparency (Cambridge University Press, 2007) 73.

${ }^{27}$ Employment Relations Act 2000 (NZ) s 3(a)(ii).

${ }^{28}$ Ramachandran (n 24) 1044.

${ }^{29}$ Ibid 1060.

${ }^{30}$ Hannah Riley Bowles, Linda Babcock and Lei Lai, 'Social Incentives for Gender Differences in the Propensity to Initiate Negotiations: Sometimes It Does Hurt to Ask' (2007) 103 Organizational Behavior and Human Decision Processes 84.
} 
norms that make women carry more of a burden of family responsibility may also make it harder for women to negotiate. ${ }^{31}$

Transparent pay information will not only empower women with information to improve their negotiation skills, it may also reduce the need to negotiate. Greater pay transparency will make pay disparities subject to greater scrutiny. Knowing this will encourage employers to set pay rates based on legitimate and justified grounds, such as proven performance. This is surely preferable to a system of unfettered managerial discretion, which may hide favouritism or discrimination and may be overly weighted towards rewarding those with the best negotiation skills rather than those who are best at their jobs. ${ }^{32}$

In short, improved pay transparency would not only make it easier for women to negotiate, it might reduce the need for negotiation, forcing employers to appoint and promote on other factors rather than negotiating ability.

\section{Privacy and Cost Concerns}

Privacy and confidentiality concerns should not be used as a pretext for failure to implement transparency. While many New Zealanders may be inculcated with a social norm that it is bad form to discuss wages, this norm should not be allowed to pass uninterrogated. Privacy norms can shift, and sometimes it is for the greater good that they do. ${ }^{33}$ History is replete with examples of matters that were once viewed as belonging to the private sphere where the state should not intervene - rape in marriage and corporal punishment of children are two examples of this - but those social norms have shifted and society is better for it. Confidentiality around wages is not for the benefit of employees, even if some employees on undeservedly higher salaries than their colleagues reap the benefits of it.

Employers may feel threatened by a new culture of transparency and the loss of the ability to exercise managerial prerogative unscrutinised, but employers with nothing to hide have nothing to fear. They may benefit from the cachet of being an employer who is known not to discriminate and may also serve as exemplars of best practice. ${ }^{34}$ Decent employers should want to know if they have problems so that they can take steps to fix them.

Employers may worry that pay transparency could have a negative effect on morale. However, there is research that suggests that pay transparency can improve worker satisfaction by fostering perceptions of fairness. ${ }^{35}$ The United States Department of Labour Women's Bureau succinctly makes the business case for 'open pay', stating that such policies

\footnotetext{
${ }^{31}$ Ramachandran (n 24) 1060.

32 See, generally, Estlund (n 10) 799.

${ }^{33}$ For discussion on changing attitudes to privacy around pay rates, see Marianne Delpo Kulow, 'Beyond the Paycheck Fairness Act: Mandatory Wage Disclosure Laws — A Necessary Tool for Closing the Residual Gender Wage Gap' (2013) 50 Harvard Journal of Legislation 385, 431.

${ }^{34}$ Belinda Smith, 'How Might Information Bolster Anti-Discrimination Laws to Promote More Family-Friendly Workplaces?’ (2014) 56 Journal of Industrial Relations 547.

${ }^{35}$ See, for example, Estlund (n 10) 781.
} 
[s]top speculation about pay — workers will know they are being paid fairly[;] [m]ake it clear that top performers are rewarded, which creates an incentive to work harder[;] [s]top meritless complaints about unequal pay[; and] [i]dentify pay disparities so they can be fixed. ${ }^{36}$

There may also be resistance to the idea of pay transparency on the grounds of cost to employers and to the state. However, these costs must be weighed against costs of discrimination and inequality, which are currently being borne by women.

This is not to suggest that privacy and cost concerns are irrelevant, but they should not be overstated or overprivileged. They can, to an extent, be addressed in the design of the pay transparency requirements.

\section{PAY TRANSPARENCY DESIGN}

There is a range of options for the design of a pay transparency regime. A detailed blueprint is beyond the scope of this article, but research suggests the following guiding principles: ${ }^{37}$

- the information should be universal and accessible to user groups

- there should be penalties and incentives around both reporting and improving performance.

\section{A Universal and Accessible Information for User Groups}

It is arguable that the maximum benefits of transparency will only be achieved when complete pay transparency applies universally to all employers and employees as an accepted way of life. There is some precedent for this: in Norway, information on the pay of every single employee is publicly available to any interested party through the tax system. ${ }^{38}$

There are other alternatives to universal transparency that may be more palatable, at least initially. In Denmark, employers with 35 employees provide gender-divided wage statistics. ${ }^{39}$ In Australia ${ }^{40}$ and the United Kingdom, ${ }^{41}$ it is only larger employers who are forced to report to an agency.

The design of the transparency regime should take into account the potential information users, and the information made available should be carefully tailored to their needs. According to Fung, Graham and Weil, transparency requirements are only effective 'when they provide ...

\footnotetext{
${ }^{36}$ Cited in Kulow (n 33) 429.

${ }^{37}$ Fung, Graham and Weil (n 26) 177-79.

${ }^{38}$ Lars Bevanger, 'Norway: The Country Where No Salaries Are Secret', BBC News (Web Page, 22 July 2017)

$<$ https://www.bbc.com/news/magazine-40669239>.

${ }^{39}$ Bennedsen et al (n 10).

${ }^{40}$ For an overview and critique of the Australian initiatives in the area, see Belinda Smith and Monica Hayes, 'Using Data to Drive Gender Equality in Employment: More Power to the People?' (2015) 28 Australian Journal of Labour Law 191.

${ }^{41}$ Employers with 250 or more staff must report in the United Kingdom. See 'Search and Compare Gender Pay Gap Data', Gender Pay Gap Service (Web Page) <https://gender-pay-gap.service.gov.uk>.
} 
facts that people want $\ldots$ in times and places and ways that enable them to act' ${ }^{42}$ Such information must be presented in ways that are easily comprehensible and enable people to 'substantially improve their choices without imposing significant additional costs'. ${ }^{43}$

This guideline suggests that different levels of transparency could be required depending upon the purpose for which the information is needed. The general public has little need to know exactly what a given individual in an organisation earns, but this information may be relevant to that person's colleagues who are seeking pay rises or who suspect they have been discriminated against. Individuals applying for a position in the organisation could also find this information of use. In these circumstances a statutory right to request information directly from the employer could meet the need.

The general public and third parties such as unions or non-governmental organisations may have an interest in more general trends, with a view to identifying where to direct consumer and civil society pressure. These needs could be met by requiring employers over a certain size to publish a standard format statement on their website indicating the gender pay gap at an organisation level, noting any steps taken to improve it and any improvements over time.

There could also be a place for a third party agency, such as Australia's Workplace Gender Equality Agency or an expansion of the Human Rights Commission, who could be charged with receiving and processing reports from employers and reporting on selected aspects. This would potentially serve an educative function in terms of disseminating best practice and making employers aware of what is happening within their own organisations as well as allowing them to make comparisons among themselves.

The information reported to this hypothetical third party agency could also be designed to be useful to the state for purposes of enforcement, or potentially to guide procurement choices as is discussed in the next section.

\section{B Penalties and Incentives for Reporting and Improving Performance}

In order to realise the full potential of transparency it must be mandatory. The United Kingdom experience was that when reporting was voluntary there was very little uptake. ${ }^{44}$ Even when it is compulsory an absence of penalties for non-reporting can lead to non-compliance, so there must be substantial penalties for not reporting or misreporting. ${ }^{45}$

However, there should also be rewards for compliance with reporting requirements and for improvements. There is a growing awareness that consumers care about how workers in

\footnotetext{
${ }^{42}$ Fung, Graham and Weil (n 26) xiv.

${ }^{43}$ Ibid 55.

${ }^{44}$ Voluntary uptake was so low initially that in 2017 reporting was made mandatory.

${ }^{45}$ Fung, Graham and Weil (n 26) 45 emphasise the presence of 'substantial fines or other penalties for nonreporting and misreporting' in successful transparency regimes.
} 
individual workplaces are treated ${ }^{46}$ and gender equality is part of that picture. The government has the power to make sure this information is before the public's eye. The government also has the power to reward businesses who are exemplary in their reporting and practice through preferential access to government contracts.

In fact, the New Zealand government's Supplier Code of Conduct already provides the foundation for such a measure. It explicitly states that suppliers to New Zealand's government are expected to 'be transparent about their ethical policies and practices' and to 'comply with New Zealand employment standards and maintain a workplace that is free from unlawful discrimination'. ${ }^{47}$ The next stage is surely to monitor and enforce this as well as to reward businesses who comply.

\section{CONCLUSION}

Discrimination is unlawful and it is unjust. At present, the onus is on women to enforce their rights to non-discrimination and to negotiate their pay, and they are expected to do this without access to adequate information. Pay transparency would transfer the burden to the party with more power: the employer.

Employers are required by law not to discriminate against women; it is reasonable to require them to know and show that they are not engaging in discrimination. Good employers will want to change any discriminatory practices, bad employers should face the consequences of failure to do so. The New Zealand government is obliged to 'take all appropriate measures to eliminate discrimination against women in the field of employment' ${ }^{48}$ Pay transparency will facilitate monitoring, measurement, compliance and enforcement of the law, and it is accepted internationally as an essential component to furthering gender equality. It is time that gender pay transparency was introduced in New Zealand.

\footnotetext{
46 'More Consumers Consider Worker Rights before Buying', Employment New Zealand (Web Page, 12 August 2019) <https://www.employment.govt.nz/about/news-and-updates/more-consumers-consider-worker-rightsbefore-buying $>$.

47 'Supplier Code of Conduct', New Zealand Government Procurement (Web Page) $<$ https://www.procurement.govt.nz/broader-outcomes/supplier-code-of-conduct $>$.

${ }^{48}$ See above $\mathrm{n} 7$ and accompanying text.
} 